\title{
Postgraduate studies (1978-1985) at the Medical Faculty of the University of Tuzla, Tuzla, Bosnia and Herzegovina*
}

\author{
Husref Tahirovic ${ }^{\prime *}$ \\ Department of Medical Sciences \\ Academy of Sciences and Arts of \\ Bosnia and Herzegovina \\ ${ }^{* *}$ Corresponding author:
husref.tahirovic@untz.ba
Tel./Fax.: + 38535303740
}

Received: 2 March 2015

Accepted: 12 March 2015

Key words: Education - Postgraduate studies - Medical Faculty - Tuzla • Bosnia and Herzegovina

\begin{abstract}
The Postgraduate studies (PS) at the Medical Faculty (MF) of the University of Tuzla (UT) were founded with the aim of training future staff of the MF in scientific research work. The course lasted four semesters. Up to 1986, classes were attended by five generations or 141 postgraduate students, and 57 of them received their Master's degree (MSc's). Classes were held every week on Fridays and Saturdays. One part of the classes was taught at the MF in Szeged (Hungary). Besides teachers from the UT, classes were also taught by teachers from other universities from the former Yugoslavia and abroad. The most important textbooks were: Cell and Molecular Biology by de Robertisa, Mathematics and statistics for use in pharmacy, biology, and chemistry by Saunders \& Fleming, and Kako se pišu saopštenja o medicinskim istraživanjima (How to write reports of medical research) by Rajko Igić. Searching the index base Pub Med at the end of 2014, by the surnames and initials of the names of the 57 masters, we found that they had published 14 articles before completing their MSc's and 821 articles after completing their Master of Science. Later, 35 masters received $\mathrm{PhDs}$ and were appointed assistant professors, and later they were also appointed to higher ranks. Conclusion: Looking at the results of the PS, MF of the UT in the above mentioned period, it can be said that the PS was the place where the formation began of the future scientific and teaching staff of the MF in Tuzla.
\end{abstract}

\section{Introduction}

The Faculty of Medicine in Tuzla was founded in 1976 and already in 1978, on the basis of a proposed study on founding a postgraduate course and a motion by the Faculty Board, at its session on 15 October 1978 the faculty council rendered a decision to launch a post-graduate study course (PS) (1). The aim of founding this course was to train fu- ture staff of the medical faculty in scientific research work in the field of pre-clinical and clinical disciplines (2). The curriculum and course programme (3) were in many ways original and significantly different from the curricula of other such courses in the former Yugoslavia. While it was being drawn up, account was taken of the fact that doctors and experts in the field of related branches of biomedicine who wanted to work in research

\footnotetext{
${ }^{\star}$ A shorter version of this article was published in the journal "Medici.com". The amended and supplemented version in English is published with the consent of the journal Medici-com. ${ }^{*}$ The author of the text was one of the fifth generation of post-graduate students from the Faculty of Medicine in Tuzla.
} 
should be acquainted with the necessary knowledge of scientific research work, as seen in acquisition of knowledge of English language, cell biology, biostatistics, research methodology and publication. The course lasted 4 semesters, during which the following subjects were taught: English language I and II, Biostatistics I and II, General Methodology of Scientific Research Work, Cell Biology, Medical Writing I and II, Selected Medical Research, Ideas in Biomedical Sciences, Medical Science and Civil Defence, Optional Subject, Creation of Master of Science (MSc) Thesis Project, and MSc Thesis. The fourth and final semester was planned for drawing up the project and writing the MSc thesis. The administrator of the course from its foundation and until 1985 was Prof. Dr. Rajko Igić, at that time the pro-dean for teaching and science of the Medical Faculty in Tuzla (Box 1, Figure 1).

The first generation of post-graduates were mainly employees of the Medical Faculty and the Clinical Centre in Tuzla, but also from other medical institutions in Tuzla, whilst only a few of them were from other cities. Later, the number of post-graduates

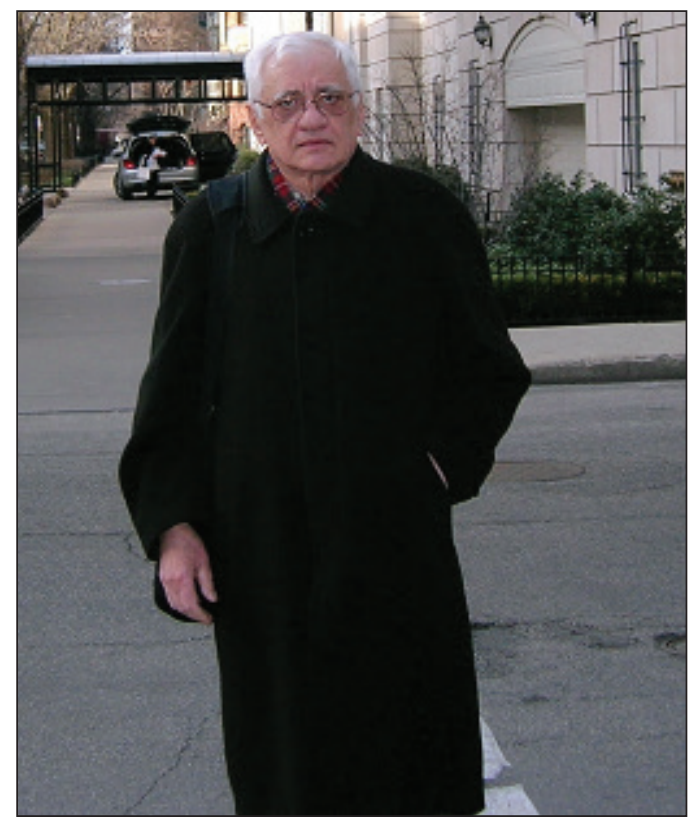

Figure 1 Prof. dr. Rajko Igić.

\section{Box 1 \\ Biography of Prof. Dr. Rajko Igić}

Rajko Igić was born in Despotovo, Serbia, 1937. He attended High School (Gymnasium) in Sombor. He received his MD degree in Belgrade, his MSc in pharmacology and $\mathrm{PhD}$ from the Medical Faculty of the University of Sarajevo, Bosnia and Herzegovina (BH). He spent two years at the University of Oklahoma in Oklahoma City, as a Fulbright Exchange Visitor. His adviser was Dr. Ervin Erdos. Dr. Igić worked for two years as a physician in Sombor and became a research assistant, then assistant professor at the medical faculty in Sarajevo. In 1978 Professor Igić founded the Department of Pharmacology at the Medical Faculty in Tuzla and served as chairman there, and he served as chairman of the Postgraduate Studies. Dr. Igić was a Visiting Professor at the Medical Faculty in Banja Luka. He initiated and led the campain of Yugoslav medical students, A Day Without Smoking - January 31st that has now become the National Day Without Smoking. Dr. Igić was a recipient of the Veselin Masleša Award, and he received the Yu-Humanist Award from Croatia. The Parliament of the $\mathrm{BH}$ elected him in 1991 as director of the Department for Scientific Exchanges. Dr. Igić was editor-in-chief of the Acta Medica Saliniana, Kontakt (Contact), and Scripta Medica. He has published several textbooks and a large number of research papers. He is a member of the Academy of Sciences and Arts of the Republika Srpska. He now lives in Chicago, where he worked as a Senior Scientist at the Stroger Hospital of Cook County.

from other, mainly neighbouring towns, increased from year to year. By 1986 the course had been attended by five generations of students, that is, 141 graduates, of which 57 attained their MSc degree. With the launch of this course, international cooperation began between the newly founded Medical Faculty in Tuzla, and in a relatively short period of 
time rose to an enviable level. For the PS, cooperation with the Medical Faculty in Segedin (Hungary) and the Medical Faculty of the University of Shinsu, Matsumato, Japan was particularly important $(4,5)$. In the opinion of most of the post-graduate students of all generation from that period, the launch of the PS meant the refreshment of the medical academic community in Tuzla, refreshment, which in medical circles changed the previous way of thinking and attitude towards scientific research work.

\section{How were the classes organized?}

The classes in the PS course were held on Fridays and Saturdays. The lectures were interactive and were interesting and up to date, with the emphasis on acquiring knowledge and skills in scientific research and publication. In addition, most of the graduates had a responsible attitude towards meeting their study obligations, which was primarily reflected in their interest in active participation in acquiring new knowledge.

Some of the teaching took place at the Medical Faculty in Segedin, with which cooperation was established from the very beginning of the course, on the basis of an international agreement between the University in Tuzla and the Medical Faculty in Segedin (Hungary), signed by their rectors (4). These were compulsory scientificprofessional trips for the post-graduate students, to visit the institutes and clinics of the Medical Faculty in Segedin, lasting seven days. All the classes there were held in English, in the form of lectures, demonstrations and work at individual institutes and clinics of the Medical Faculty in Segedin. Those who participated in these trips showed great interest during the classes, and the lecturers were eminent teachers from the Medical Faculty in Segedin, who were prepared to pass on their rich experience to the graduate students, in the field of scientif- ic research work. In addition, the close and friendly relationship between the teachers from Segedin and the graduates from Tuzla made it possible to establish new forms of cooperation, which resulted in the fact that many teachers from Segedin gave lectures in Tuzla and acted as tutors for the MSc theses of our students.

\section{Who taught the Postgraduate studies course?}

Alongside the teachers from the University in Tuzla, courses in the PS at the Medical Faculty in Tuzla were also given by teachers from the Universities of Sarajevo, Belgrade, Zagreb, Ljubljana, Novi Sad, Banja Luka and Split. The teaching staff at the Military Medical Academy and the Military Technical Institute in Belgrade gave lectures on research in toxicology and held classes (for all generations) in the subjects of Medical Science and Civil Defence. At that time, teaching staff from abroad came from the USA, Japan, Germany, England, Hungary, Denmark and Sweden (6). The greatest number of teaching staff from cities in the former Yugoslavia came from Belgrade and Zagreb - a total of eighty-five, then from Sarajevo (18), Ljubljana (9), Novi Sad (5), Skopje (2), from Split and Banja Luka one each, and from other countries of that time there was a total of 29 lecturers (6). The best known among them was Ulf Svante von Euler, a Nobel Prize winner from Sweden (Figure 2) (7). Immediately before he came to Tuzla in 1982 a brochure was published entitled "Lecturers in the Post-graduate Course: Ulf Svante von Euler" (Figure 3).

\section{What texts were used for teaching?}

The textbook for the main subject, Cell Biology, of the PS of the Medical Faculty in Tuzla was the book: Cell and Molecular Biology, by de Robertis. As well as the Medical Facul- 


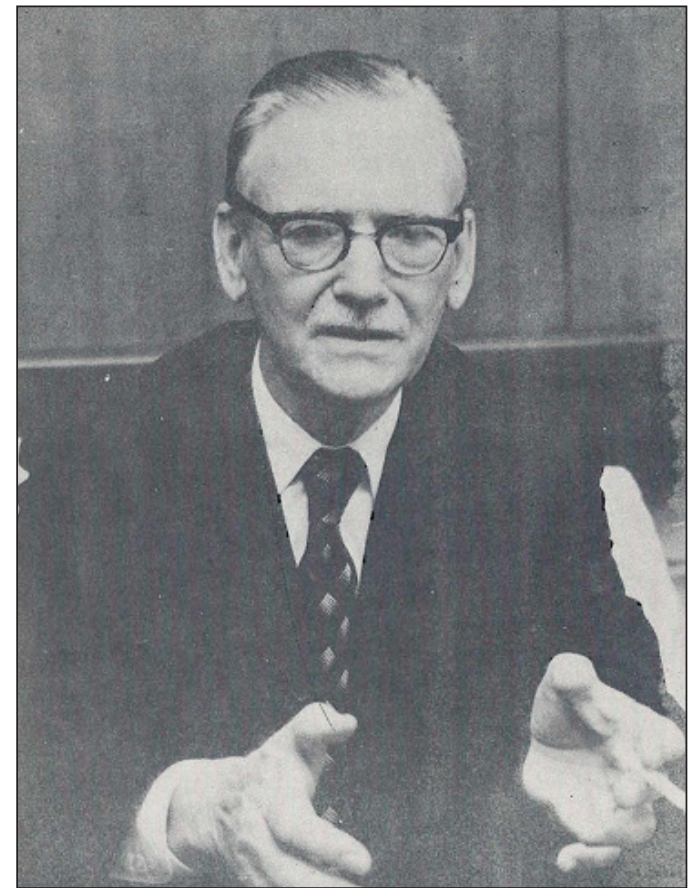

Figure 2 Nobel Laureate, Ulf Svante von Euler.

ty library, most post-graduate students also purchased this book, so tens of copies of this excellent textbook made their way to Tuzla at that time. This subject was run by the academician Mihovil Proštenik (biochemist expert in cell membranes, from Zagreb), Prof. Dr. Abdulah Nakaš and Prof. Dr. Asim Jamakosmanović (physiologists from Sarajevo), Prof. Dr. Biljana Plavšić (biologist, an expert in the electronic microscope from Sarajevo) and Prof. Dr. Ljubomir Berberović (biologist and geneticist from Sarajevo). The following books were recommended for the subject "General Methodology of Scientific Research Work and Medical Writing": Kako nastaje naučno djelo (How to Write a Scientific Study) by academician Midhat Šamić from Sarajevo, Kako sastaviti, objaviti i ocijeniti znanstveno djelo (How to draw up, publish and assess a scientific study) by academician Vlatko Silobrčić from Zagreb, and Uvod u medicinska istraživanja (Introduction to Medical Research) by Prof. Dr. Milorad Miro Mimica from Zagreb. Statis-

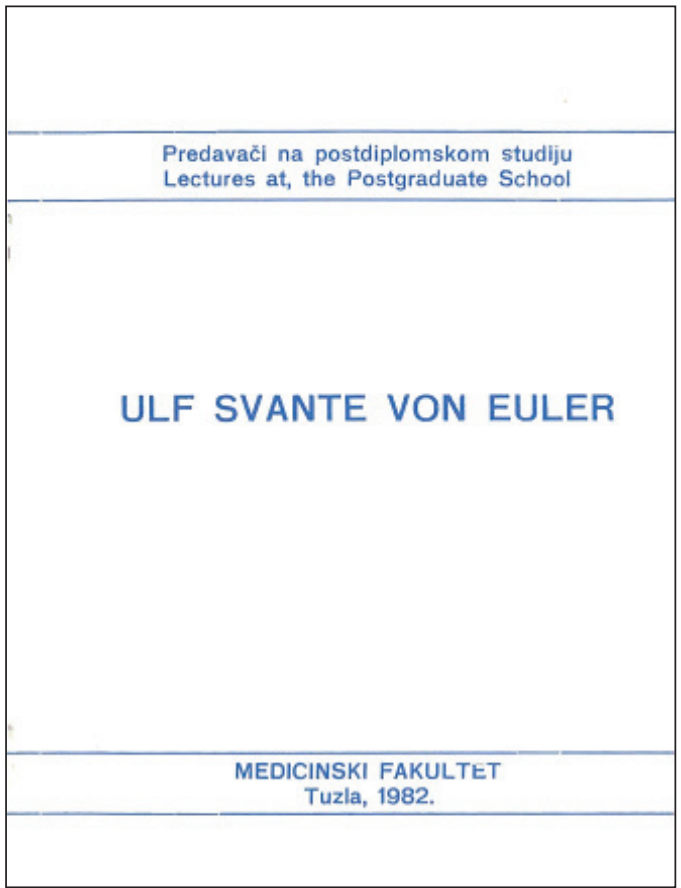

Figure 3 Cover sheet of brochures printed on the occasion of the arrival of Nobel Laureate UIf Svante von Euler on a visit to the Medical Faculty of the University of Tuzla.

tics were studied from the textbook Osnovne statističke metode za nematematičare (Basic Statistical Methods for Nonmathematicians) by Prof. Dr. Boris Petz from Zagreb and the book Mathematics and statistics for use in pharmacy, biology, and chemistry by Saunders \&Fleming, and knowledge of scientific information was obtained from the textbook Znanstvene informacije (Scientific Information) by Prof. Dr. Helena Pavić from Zagreb.

Alongside the recommended literature that existed on scientific research work, for the first generation of post-graduate students, Prof. Dr. Rajko Igić issued script notes entitled Kako se pišu saopštenja o medicinskim istraživanjima (How to write reports in Medical Research) with a print run of 100 copies. Due to the great interest in that text shown by post-graduate students, not only at the Medical Faculty in Tuzla but also at other medical faculties in the former Yugo- 
slavia, the publisher Veselin Masleša from Sarajevo published the text in the form of a book, with a print run of 1000 copies. That book was also recommended for other postgraduate courses at Medical Faculties in the former Yugoslavia. At that time it was the first book of its kind in our language, dealing with the issues involved in publishing scientific and scholarly medical texts. Later the book was cited many times in similar publications written in the former Yugoslavia. The same author also wrote brochures for the post-graduate course entitled: Planiranje eksperimenta u kliničkim istraživanjima (Planning experiments in clinical research) (1981), Osnovi planiranja i statističke evaluacije bioloških, farmakoloških i kliničkih istraživanja (The bases of planning and statistical evaluation of biological, pharmacological and clinical research) (1985) and Uputstva za pisanje doktorske dizertacije $i$ magistarskog rada (Instructions for writing $\mathrm{PhD}$ dissertations and MSc theses) (1991), which alongside the recommended books, were the relevant textbook literature. As well as these textbooks, the teaching materials frequently used, both in classes and out of them, also included a series of publications from the index bases Current Contents, Index Medicus, Excerpta Medica, and tens of bio-medical journals from abroad, and many MSc and $\mathrm{PhD}$ papers by doctors from Tuzla and other cities of the former Yugoslavia.

\section{Was the intended aim achieved, and to what extent?}

The post-graduate course at the Medical Faculty in Tuzla was founded with the aim of preparing and training post-graduate students (future staff of the Medical Faculty in Tuzla) for scientific research work in the field of pre-clinical and clinical disciplines. The original idea to send each year 2 to 3 doctors from Tuzla for post-graduate studies to Sara- jevo, Belgrade, Zagreb or some other centres of the former Yugoslavia, in order to train them for scientific research work, was unacceptable for Professor Rajko Igić. As a result he initiated the foundation of the post-graduate course at the Medical Faculty in Tuzla, with the explanation that it was better and more effective for experienced professors to come to Tuzla from other centres, than to send a small number of doctors to study at other centres. His idea was accepted and very quickly completely realized, thanks to the understanding of those responsible for the development of the faculty, primarily the dean, Prof. Dr. Ibro Pašić and the president of the Executive Board of the Municipality of Tuzla, Mr. Ljubimir Jurak.

In order to evaluate the success of the foundation and work of the PS course at the newly opened Medical Faculty in Tuzla, it was necessary to reply to the question whether and how far the intended aim had been realized. In order to answer that question I verified the number of publications before and after the graduation of the first five generations of post-graduates, because publication is necessary for further progress in an academic career, and how far the MSc graduates in biomedical sciences of those generations contributed to resolving the problem of the lack of staff at the Medical Faculty in Tuzla.

Using the key words of the surnames and initial of the $57 \mathrm{MSc}$ graduates who were post-graduate students in the first five generations of the PS, I searched the number of articles they had published, before and after graduation, in journals indexed in PubMed/ MEDLINE up to 2014. Before they completed their MSc, 14 articles were published, and afterwards 821 (Figure 4).

Data for this survey were collected from PubMed/MEDLINE using the keywords Bosnia and Herzegovina and 2014.

Most of those who received their MSc degree, 35 of them, later received a $\mathrm{PhD}$ 


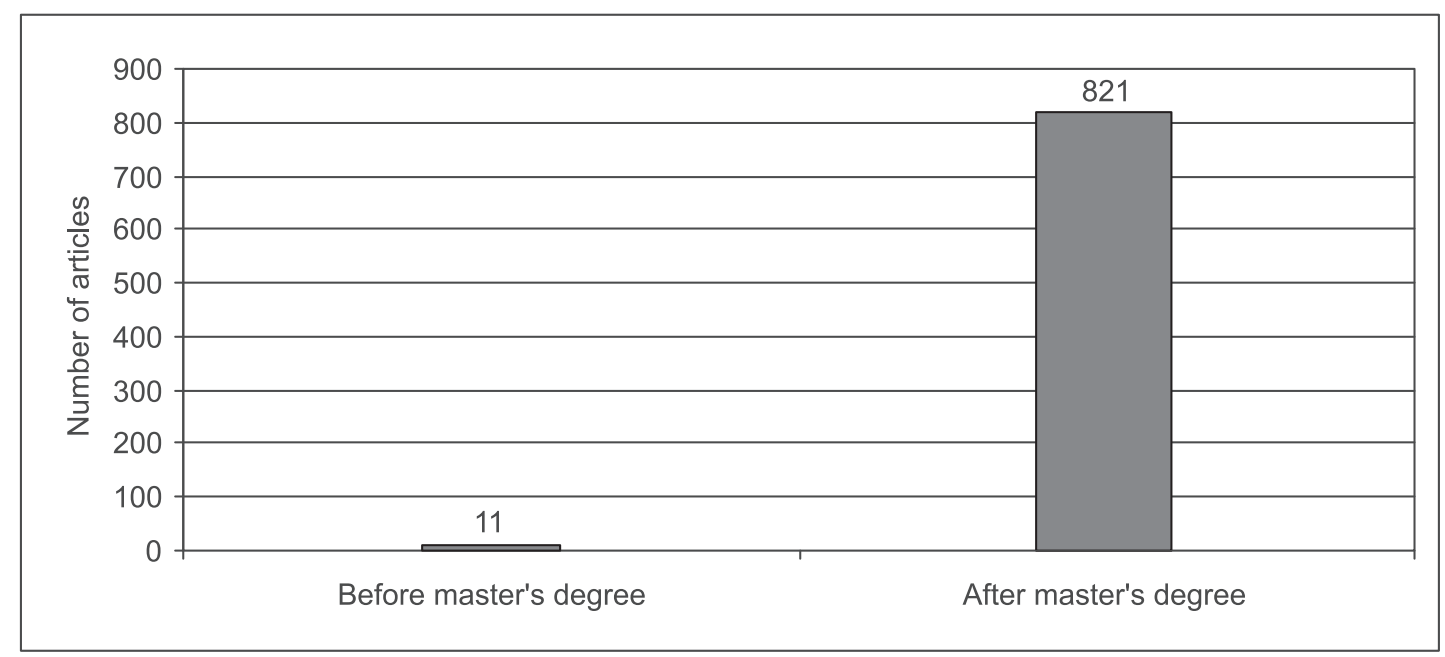

Figure 4 The number of articles before and after Master's degree of 57 graduate students published in journals indexed in PubMed/MEDLINE.

from the Medical Faculty in Tuzla or another Medical Faculty and were promoted to the position of assistant professor, and later extraordinary and regular professors, which was a significant contribution to resolving the problem of the lack of staff, but also to improving the professional and scientific work of the Medical Faculty and the University Clinical Centre in Tuzla. Some of the MSc graduates from this post-graduate course continued their careers abroad after the war broke out in 1992 and, in both a professional and a scientific sense, achieved excellent results. The author of this article and Prof. Dr. Mirsada Hukić were post-graduates in those generations, and later they were appointed members of the Academy of Sciences and Arts of Bosnia and Herzegovina.

Prof. Dr. Miralem Pašić, a graudate from this course who continued his career abroad and who in a professional and scientific sense has achieved excellent results, recently wrote this to the author of this article: "Seen from a distance of 35 years, I still believe today that the Post-graduate course of Professor Igić was one of the key pioneering moves in medicine in Tuzla. For us, the post-graduate students, Prof. Igić opened up new perspectives in our lives and science, introducing us to the world of scientific research work. He guided us to think scientifically, to observe and analyse both patients and illness, but also the world and the environment. I am extremely grateful to Prof. Igić for his visionary ideas and the work he did in our town."

\section{Conclusion}

The development of post -graduate course presented in this paper enlightened the basis for the formation and continuation of scientific as well as educative work of the Medical Faculty in Tuzla, which effects have been felt over a much wider area. Therefore this paper, based both documents and personal experience, elucidates important segment of formative period of academic development in Tuzla.

Conflict of interest: The author declares that he has no conflict of interest.

\section{Sources and references}

1. Archive of the Medical Faculty, University of Tuzla. Decision on the establishment of postgraduate studies at the Medical Faculty of the University of Tuzla. Number: 01/1-2214/2 of December 27, 1978. 
2. Postgraduate studies at the Medical Faculty of University of Tuzla. Bulletin of the University of Tuzla.1979;3(7):224-7.

3. Archive of the Medical School, University of Tuzla. The curriculum of the postgraduate studies at the Medical Faculty of the University of Tuzla, 1978 years.

4. The program of international cooperation of the Medical Faculty in Tuzla in 1981 to 1982 year. Bulletin of the University of Tuzla.1981;5(11):224-7.
5. Igić R. International cooperation of Medical Faculty of the University of Tuzla. Bulletin of the University of Tuzla. 1983;7(15):224-7.

6. Hadžiahmetović I. editor. Twenty years of the Faculty of Medicine, University of Tuzla, 1976 to 1996. Tuzla: Medical School Tuzla; 2001. pp. 165-8.

7. International and inter-university cooperation: Visits of delegations and personalities to University of Tuzla. Bulletin of the University of Tuzla. 1982;6 (13): 208-9. 